Presentación 


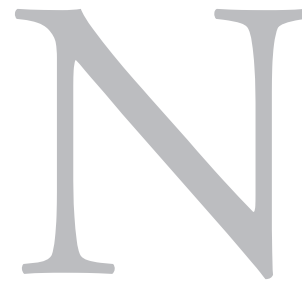

o ano 2018 cumpríronse quince anos da morte de Lois Tobío Fernández. Non queriamos deixar pasar esta data sen máis. Sen dúbida, nun país coma o noso, de tan pouca e ás veces mala memoria, a súa figura segue aínda a precisar de moita reivindicación tendo en conta que se trata dun referente fundamental para poder comprendermos a nosa Galicia contemporánea.

A andaina vital de Tobío (1906-2003) cobre todo o século vinte. Pertence a unha xeración de humanistas e renacentistas que o deron todo por servir a Galicia dende todos os saberes e situacións. E foi Tobío un persoeiro dunha madeira especial, traballador incansable e abnegado, un galego de lei, militante ao cento por cento nas cousas do país, en todo o que sentía no máis fondo, comprometéndose sempre no que cría. En palabras de Ramón Villares, é unha das voces máis esenciais da «outra Galicia», isto é, dunha das Galicias posibles, pero que a inclemencia da historia acabou malogrando.

A herdanza global que nos deixou é a dun galeguista universalista, a convicción de quen comprendeu á primeira vista o imponderable valor da identidade como clave para se entender co mundo, para se desenvolver sen lindeiros, sen perder o norte irrenunciable das orixes. Ese Tobío que deambula pola diplomacia, pola investigación histórica, pola tradución poética ou ensaística e polo xornalismo é o mesmo Tobío do Seminario de Estudos Galegos, do anteproxecto de Estatuto de autonomía para Galicia, do Consello de Galiza..., porque foi parte dun colectivo formado e educado na valiosísima idea do progreso con identidade, do positivo valor do achegamento ao exterior para sermos máis e mellores. É o universalismo galeguista que debería ser o noso pan de cada día, a nosa biblia en tempos de mundialización. 
O universalismo de Tobío foi esencialmente político e cultural, fundamentado na firme convicción de que non se trataba de erguer valados senón de cultivar o noso xardín, como el explicaba, no que se dan flores distintas ás doutros, pero todas para enriquecemento da vida de toda a humanidade. Nada máis afastado, pois, desas ideas hoxe en voga de que os nacionalismos son un paso atrás, desestabilizadores, inviables, vencellados a proxectos autoritarios ou que van contra corrente.

Tobío e os galeguistas sempre estiveron abertos ao exterior, onde pensaban que podían atopar exemplo e axuda, fuxindo da reclusión e a introversión que os podía levar a se converter en «nacionalismos de campanario por un exceso de purismo», en palabras súas.

A atracción de Tobío por outras culturas é experimentada dende os anos mozos, nas súas lecturas de Montaigne e outros autores románticos e malditos que o introducirán na literatura francesa, que tanto amou e á que tanto lle debería, segundo el mesmo asegurou, en formación e gozo. O seu seguimento activo da vida cultural en todas as cidades e lugares onde viviu, de Europa a América, de Berlín a Montevideo, acrecentou esa ampla cosmovisión capaz de unir e relacionar a Van Gogh e Castelao, de apreciar o alleo valorando o propio na súa xusta medida, sen estridencias nin excesos de ningún signo.

$\mathrm{Na}$ xornada que organizamos en Viveiro (Lugo), afondamos en tres dimensións - non todas as reivindicables- que formaron parte destacada da súa traxectoria vital: o compromiso político como galeguista, a súa vocación de tradutor e tamén de xornalista. Tobío era moito máis: o diplomático e universalista, o investigador, o mestre... Argallamos un programa conciso que foi debullado por especialistas ben coñecedores da súa condición intelectual. Todos e todas, en maior ou menor medida, gozaron do contacto persoal con quen tanta humanidade transmitía. Quixemos facelo, ademais, no seu Viveiro natal e coa presenza de Constanza, a súa filla, a quen lle agradecemos a asistencia, así como á alcaldesa, María Loureiro García, e ao cronista oficial da vila, Carlos Nuevo. 
Na Comisión de Acción Exterior do Consello da Cultura Galega iniciamos con Lois Tobío unha liña de reflexión coa aspiración de profundar nas figuras máis excelsas do universalismo galeguista, unha perspectiva que nos sitúa nese mundo no que pretendemos ser nós mesmos e que hoxe en día tamén cómpre destacar.

O compromiso galeguista e universalista de Tobío, de quen quixo e soubo exercer de galego por ese mundo adiante que voluntaria e involuntariamente debeu percorrer, é o dunha voz políglota e singular que precisamos reivindicar e divulgar para que o seu alento nobre e cosmopolita permaneza para sempre entre nós.

\section{Xulio Ríos}

Coordinador da xornada e da Comisión de Acción Exterior (CCG) 